Jonathan Victorius, Nigar Pandrianto, Yugih Setyanto: Pengaruh Komunikasi Efektif Pada Perkuliahan Fotografi Saat Pandemi Covid-19 terhadap Hasil Belajar Mahasiswa Desain Komunikasi Visual

\title{
Pengaruh Komunikasi Efektif Pada Perkuliahan Fotografi Saat Pandemi Covid-19 terhadap Hasil Belajar Mahasiswa Desain Komunikasi Visual
}

\author{
Jonathan Victorius, Nigar Pandrianto, Yugih Setyanto \\ jonathan003010@gmail.com,nigarp@fikom.untar.ac.id,yugihs@fikom.untar.ac.id
}

Fakultas Ilmu Komunikasi Universitas Tarumanagara

\begin{abstract}
Effective communication is defined as communication that can bring about a change in attitude. Effective communication aims to make it easier for others to interpret the message conveyed by the messenger. Effective communication is very important in improving student learning outcomes. At the time of the Covid-19 pandemic, the e-learning learning method became the learning method used by all universities. Learning outcomes refer to the achievements obtained by students in teaching activities through updating and creating their own behavior. This research was conducted to measure the effect of effective communication on student learning outcomes. This study uses quantitative techniques with survey methods and makes Visual Communication Design students the object of research. The main data were collected by distributing questionnaires to 70 respondents. Data analysis in this study used the Statistical Package for the Social Sciences with the SPSS for Windows 25 application. Based on the results of the study, it was found that effective communication had a significant and positive effect on student learning outcomes. Effective communication has an effect of $67.4 \%$ on student learning outcomes, while the other $32.6 \%$ is another factor. Thus, the higher an effective communication, the learning outcomes will also increase. Vice versa, the lower an effective communication, the learning outcomes will also decrease.
\end{abstract}

Keywords: effective communication, learning outcomes, photography

\begin{abstract}
Abstrak
Komunikasi yang efektif diartikan sebagai komunikasi yang dapat mewujudkan perubahan sikap. Komunikasi yang efektif bertujuan untuk mempermudah orang lain menafsirkan pesan yang diberitahukan oleh penyampai pesan. Komunikasi yang efektif sangat penting dalam meningkatkan hasil belajar mahasiswa. Pada saat pandemi Covid-19, metode pembelajaran e-learning menjadi metode pembelajaran yang digunakan oleh semua universitas. Hasil belajar merujuk pada prestasi yang diperoleh mahasiswa dalam kegiatan mengajar melalui pembaharuan dan pembuatan tingkah laku sendiri. Penelitian ini dilakukan untuk mengukur pengaruh komunikasi efektif terhadap hasil belajar mahasiswa. Penelitian ini menggunakan teknik kuantitatif dengan metode survei dan menjadikan mahasiswa Desain Komunikasi Visual sebagai objek penelitian. Data utama dikumpulkan dengan cara menyebar kuesioner kepada 70 responden. Analisis data dalam penelitian ini menggunakan Statistical Package for the Social Sciences dengan aplikasi SPSS for windows 25. Berdasarkan hasil penelitian, diketahui bahwa komunikasi efektif memiliki pengaruh yang signifikan dan bernilai positif terhadap hasil belajar mahasiswa. Komunikasi efektif memiliki pengaruh sebesar 67,4\% terhadap hasil belajar mahasiswa, sementara 32,6\% lainnya merupakan faktor lain. Dengan demikian, semakin tinggi suatu komunikasi efektif maka hasil belajar juga semakin meningkat. Begitu juga sebaliknya, semakin rendah suatu komunikasi efektif maka hasil belajar juga semakin menurun.
\end{abstract}


Kata kunci: fotografi, hasil belajar, komunikasi efektif

\section{Pendahuluan}

Pandemi Covid-19 berdampak pada proses pendidikan di Indonesia. Menteri Pendidikan dan Kebudayaan (Mendikbud) Nadiem Anwar Makarim menyampaikan keputusan bahwa seluruh kegiatan belajar mengajar Semester Gasal 2020/2021 di Perguruan Tinggi dilakukan secara e-Learning. Salah satu universitas yang sudah menerapkan kegiatan pembelajaran secara online adalah Universitas Bina Nusantara Kemanggisan, Jakarta Barat. Penelitian ini fokus pada pembelajaran fotografi. Bidang Pendidikan Desain Komunikasi Visual mempelajari fotografi. Fotografi atau photography (bahasa inggris), bersumber dari yunani "photos" yang diartikan sebagai cahaya, dan "grafos" yaitu melukis / menulis. Maka dapat diartikan fotografi melambangkan proses menggambar / menulis dengan menggunakan media kamera menggunakan sumber cahaya (Karyadi, 2017).

Menurut Rakhmat (2013), agar komunikasi berjalan efektif, seseorang perlu memahami 5 hukum komunikasi efektif yang disebut REACH (Respect, Empathy, Audible, Clarity, Humble). Respect merupakan rasa hormat, dan menghargai, itu adalah aturan komunikasi nomor satu antara kita dan orang lain. Empati adalah daya kita untuk memposisikan diri pada posisi atau kedudukan yang dihadapi orang lain. Audible merupakan didengar dengan baik. Bila empati diartikan kita harus mendengarkan terlebih dahulu atau dapat menampung umpan balik dengan baik, maka Audible merupakan pesan yang kita haturkan dapat diartikan secara baik oleh penerima pesan. Clarity adalah pemahaman dari pesan itu sendiri, dengan harapan tidak melahirkan multitafsir atau tafsir yang berbeda. Terakhir yaitu Humble yaitu kerendahan hati. Sikap ini merupakan elemen yang berkaitan dengan hukum pertama, yaitu membangun rasa hormat kepada pemberi informasi. Kerendahan hati bisa diartikan menjadi apresiasi komunikator kepada komunikator sebagai penerima pesan.

E-Learning adalah cara belajar dengan memakai teknologi informasi dan komunikasi yang dapat mengubah proses cara belajar antara pengajar dan siswa. Tujuan utama memanfaatkan teknologi ini merupakan untuk mengoptimalkan efisiensi dan efektivitas pembelajaran, keterbukaan dan akuntabilitas (Murtiyasa, 2012). Berdasarkan Winataputra (2007) hasil belajar membuktikan keberhasilan siswa, dan setiap kegiatan pembelajaran dapat membawa perubahan yang unik. Berdasarkan penelitian Dimyati dan Mudjiono (2006), hasil belajar merupakan hasil interaksi antara perilaku belajar dan perilaku mengajar. Dari sudut pandang guru, perilaku mengajar diakhiri dengan proses evaluasi hasil belajar. Dari sudut pandang siswa, hasil belajar merupakan akhir dari proses belajar mengajar.

Pada dasarnya fotografi adalah aktivitas merekam dan menyulap cahaya untuk memperoleh hasil yang diingini. Fotografi dapat dibagi menjadi teknik dan seni (Marcus, 2010). Menurut Sudarma (2014), dalam penciptaan karya fotografi, teknik, prinsip, dan strategi tertentu digunakan untuk menyampaikan informasi atau pesan melalui foto. Hal yang sama juga terjadi dalam komunikasi visual. Fotografi merupakan tempat untuk menyampaikan informasi atau informasi, oleh karena itu selain prinsip kegunaan dan estetika, fotografi juga mencakup beberapa strategi penyampaian informasi.

Rumusan masalah dalam penelitian ini adalah apakah terdapat pengaruh antara komunikasi efektif terhadap hasil belajar mahasiswa. Sementara tujuan dari 
Jonathan Victorius, Nigar Pandrianto, Yugih Setyanto: Pengaruh Komunikasi Efektif Pada Perkuliahan Fotografi Saat Pandemi Covid-19 terhadap Hasil Belajar Mahasiswa Desain Komunikasi Visual

penelitian ini adalah untuk mengetahui apakah terdapat pengaruh antara komunikasi efektif terhadap hasil belajar mahasiswa. Hipotesis penelitian adalah $\mathrm{H}_{0}$ berarti komunikasi efektif tidak memiliki pengaruh yang signifikan terhadap hasil belajar mahasiswa. Sementara $\mathrm{H}_{\mathrm{a}}$ berarti komunikasi efektif memiliki pengaruh yang signifikan terhadap hasil belajar mahasiswa.

\section{Metode Penelitian}

Pada penelitian ini bertujuan untuk mengetahui pengaruh komunikasi efektif terhadap hasil belajar mahasiswa. Penelitian ini memakai metode penelitian kuantitatif dengan pendekatan survei. Metode survei adalah suatu penelitian yang mengumpulkan data atau informasi dengan cara memberikan list pertanyaan atau pernyataan kepada responden. Penggalian data dapat dilakukan melalui kuesioner dan wawancara (Sujarweni, 2019). Populasi diartikan sebagai suatu wilayah umum yang mencakup objek-objek dengan kualitas dan karakteristik tertentu yang ditentukan peneliti untuk dipelajari, dianalisis, dan diambil kesimpulannya. (Sugiyono, 2016). Populasi yang dipakai pada penelitian ini adalah seluruh mahasiswa jurusan Desain Komunikasi Visual (DKV) Universitas Bina Nusantara, Kemanggisan, Jakarta Barat, angkatan 2019.

Sampel merupakan bagian dari banyak karakteristik populasi yang dipakai untuk penelitian. Jika populasinya besar maka tidak mungkin peneliti menggunakan semuanya untuk penelitian, seumpama karena dependensi dana, tenaga dan waktu. Maka peneliti dapat menggunakan sampel yang diperoleh dari populasi tersebut. Kesimpulan yang dipelajari dari sampel maka akan diterapkan pada populasi (Sujarweni, 2019). Menurut Hair et al., untuk menentukan jumlah sampel dalam penelitian, banyaknya responden yang digunakan untuk penelitian bergantung pada banyaknya jumlah indikator penelitian dikali 5. Dalam penelitian ini, peneliti menyebarkan kuesioner kepada 70 responden yang merupakan mahasiswa DKV Bina Nusantara Kemanggisan, Jakarta Barat angkatan 2019. Penyebaran kuesioner dilakukan melalui google form untuk mendapatkan data yang sesuai dengan yang diharapkan oleh peneliti. Penelitian ini memakai teknik nonprobability sampling dengan pendekatan purposive sampling. Penelitian ini diukur dengan skala likert kemudian diolah menggunakan software SPSS versi 25 untuk menguji validitas, reliabilitas, korelasi, dan hipotesis.

\section{Hasil Temuan dan Diskusi}

Dalam penelitian ini, peneliti menyebarkan kuesioner kepada 70 responden dan mendapatkan data berupa jenis kelamin. Sebanyak 35 orang $(50 \%)$ responden berjenis kelamin laki-laki dan 35 orang $(50 \%)$ responden berjenis kelamin perempuan. Setelah melakukan uji validitas, maka berikut hasil dari uji validitas.

Tabel 1. Uji Validitas

\begin{tabular}{clcc}
\hline \multirow{2}{*}{ Variabel } & Butir Indikator & $\begin{array}{c}\text { Corrected } \\
\text { Item Total } \\
\text { Correlation }\end{array}$ & Keterangan \\
\hline \multirow{3}{*}{$\begin{array}{c}\text { Komunikasi Efektif } \\
(\mathrm{X})\end{array}$} & KBA 1 & 0,768 & Valid \\
\cline { 2 - 4 } & KBA2 & 0,643 & Valid \\
\cline { 2 - 4 } & KBA3 & 0,768 & Valid \\
\cline { 2 - 4 } & KBA4 & 0,713 & Valid \\
\hline
\end{tabular}




\begin{tabular}{llll}
\hline & KBA5 & 0,771 & Valid \\
\cline { 2 - 4 } & KBA6 & 0,734 & Valid \\
\cline { 2 - 4 } & KBA7 & 0,769 & Valid \\
\cline { 2 - 4 } & KBA8 & 0,734 & Valid \\
\cline { 2 - 4 } & KBA9 & 0,666 & Valid \\
\cline { 2 - 4 } & KBA10 & 0,664 & Valid \\
\hline Hasil Belajar & CM1 & 0,690 & Valid \\
\cline { 2 - 4 } & CM2 & 0,704 & Valid \\
\cline { 2 - 4 } & CM3 & 0,816 & Valid \\
\cline { 2 - 4 } & CM4 & 0,808 & Valid
\end{tabular}

Sumber: Hasil Pengolahan Data SPSS Versi 25

Tabel 1, menunjukkan bahwa butir-butir indikator atau pernyataan dari seluruh variabel dinyatakan valid karena seluruhnya memiliki nilai diatas 0,2.

Tabel 2. Uji Reliabilitas

\begin{tabular}{ccc}
\hline Variabel & Nilai Cronbach's Alpha & Keterangan \\
\hline Komunikasi Efektif $(\mathrm{X})$ & 0,929 & Reliabel \\
\hline Hasil Belajar $(\mathrm{Y})$ & 0,887 & Reliabel \\
\hline
\end{tabular}

Sumber: Hasil Pengolahan Data SPSS Versi 25

Tabel 2, menunjukkan bahwa setiap pernyataan dalam kuisoner dikatakan reliabel karena mendapatkan nilai Cronbach's Alpha di atas 0,6.

Tabel 3. Uji Normalitas

\begin{tabular}{lll}
\hline & & $\begin{array}{l}\text { Unstandardized } \\
\text { Residual }\end{array}$ \\
\hline $\mathrm{N}$ & & 70 \\
\hline Normal Parameters $^{\mathrm{a}, \mathrm{b}}$ & Mean & .0000000 \\
\cline { 2 - 3 } & Std. Deviation & 2.08540520 \\
\hline Most Extreme Differences & Absolute & .060 \\
\cline { 2 - 3 } & Positive & .060 \\
\cline { 2 - 3 } & Negative & -.045 \\
\hline Test Statistic & & .060 \\
\hline Asymp. Sig. (2-tailed) & & $.200^{\mathrm{c}, \mathrm{d}}$ \\
\hline Sumber: Hasil Pengolahan
\end{tabular}

Sumber: Hasil Pengolahan Data SPSS Versi 25

Dalam penelitian ini, peneliti menggunakan uji One Sample Kolmogorov Smirnov yang ada pada aplikasi SPSS Ver 25. Hasil analisis pada tabel 3 menunjukan bahwa ada nilai signifikansi sebesar 0,060 untuk residual. Hasil tersebut menyatakan bahwa distribusi data berdistribusi secara normal karena nilai signifikansi $>0,05$.

\begin{tabular}{|c|c|c|c|c|c|c|}
\hline & & & Tabe & 4. Uji T & & \\
\hline & Model & $\begin{array}{l}\text { Unstan } \\
\text { Coeft }\end{array}$ & $\begin{array}{l}\text { dized } \\
\text { ents }\end{array}$ & $\begin{array}{l}\text { Standardized } \\
\text { Coefficients }\end{array}$ & $\mathrm{t}$ & Sig. \\
\hline 1 & (Constant) & B & $\begin{array}{l}\text { Std. } \\
\text { Error }\end{array}$ & Beta & & \\
\hline & Komunikasi & 1,262 & 1,225 & & 1,030 & 0,307 \\
\hline & Efektif & 0,386 & 0,033 & 0,821 & 11,867 & 0,000 \\
\hline
\end{tabular}

Sumber: Hasil Pengolahan Data SPSS Versi 25 
Jonathan Victorius, Nigar Pandrianto, Yugih Setyanto: Pengaruh Komunikasi Efektif Pada Perkuliahan Fotografi Saat Pandemi Covid-19 terhadap Hasil Belajar Mahasiswa Desain Komunikasi Visual

Tabel 4 menunjukkan dari hasil analisis data diketahui bahwa nilai $\mathrm{t}=11,867$ dan tingkat signifikansi $=0,00<0,05$. Karena nilai $\mathrm{p}$ lebih kecil dari 0,05 , maka $\mathrm{H}_{0}$ ditolak dan $\mathrm{H}_{\mathrm{a}}$ diterima, yang berarti terdapat pengaruh yang signifikan antara komunikasi efektif terhadap hasil belajar mahasiswa.

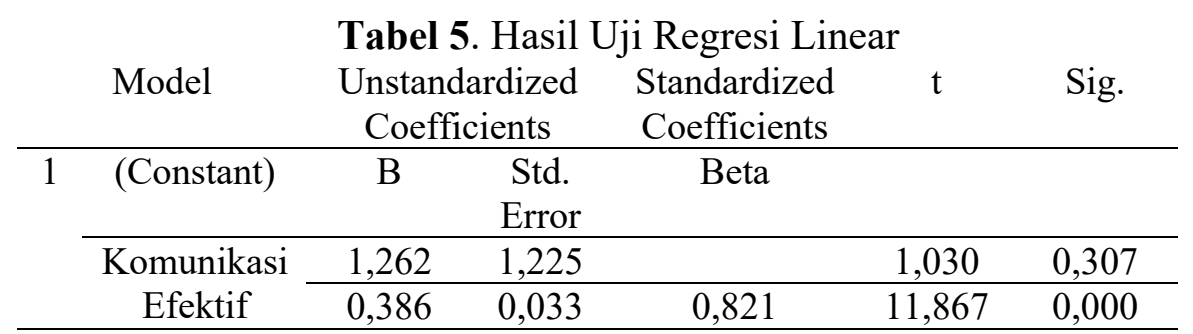

Sumber: Hasil Pengolahan Data SPSS Versi 25

Dengan keterangan $\mathrm{Y}=$ Hasil Belajar dan $\mathrm{X}=$ Komunikasi Efektif. Berdasarkan persamaan regresi linear pada tabel 5, dapat dijabarkan sebagai berikut:

1. Nilai Y (Hasil Belajar) akan tetap sebesar 1,262 konstanta jika nilai X (Komunikasi Efektif) tidak mengalami perubahan, baik peningkatan maupun penurunan.

2. Jika nilai $X$ (Komunikasi Efektif) mengalami peningkatan nilai sebesar 1 satuan, maka nilai Y (Hasil Belajar) akan mengalami peningkatan sebesar 0,386 menjadi 1,648 .

Tabel 6. Hasil Uji Korelasi

\begin{tabular}{ccccc}
\hline Model & $\mathrm{R}$ & R Square & $\begin{array}{c}\text { Adjusted R } \\
\text { Square }\end{array}$ & $\begin{array}{c}\text { Std. Error of } \\
\text { the Estimate }\end{array}$ \\
\hline 1 & $.821^{\mathrm{a}}$ & .674 & .670 & 2,10068 \\
\hline
\end{tabular}

Sumber: Hasil Pengolahan Data SPSS Versi 25

Dari hasil perhitungan Tabel 6, didapati bahwa nilai koefisien korelasi $\mathrm{R}$ sebesar 0,821 yang berada di antara interval 0,80-0,100 artinya komunikasi efektif mempunyai hubungan yang sangat kuat terhadap hasil belajar mahasiswa. Kemudian didapati juga nilai R Square sebesar 0,674 yang mengartikan bahwa 67,4\% hasil belajar dipengaruhi oleh komunikasi efektif sementara sisanya 32,6\% (100\%-67,4\%) dipengaruhi oleh faktor lain.

\section{Simpulan}

Penelitian ini menyimpulkan bahwa komunikasi efektif memiliki hubungan yang sangat kuat dengan hasil belajar mahasiswa. Berdasarkan hasil uji korelasi, diketahui bahwa nilai korelasi berada di interval 0,80 - 0,100 yang berarti komunikasi efektif memiliki peranan yang sangat kuat terhadap hasil belajar mahasiswa dan bersifat positif. Kemudian dari hasil determinasi menunjukkan bahwa komunikasi efektif memiliki peranan sebesar $67,4 \%$ terhadap hasil belajar mahasiswa. Dengan demikian, semakin tinggi suatu komunikasi efektif maka hasil belajar juga semakin meningkat. Begitu juga sebaliknya, semakin rendah suatu komunikasi efektif maka hasil belajar juga semakin menurun.

Berdasarkan kuesioner yang telah disebarkan, data pernyataan sebanyak 14 butir pernyataan dikatakan valid, karena semua pernyataan yang telah disebarkan 
memiliki nilai diatas 0,2 dan mendukung hipotesis bahwa terdapat pengaruh komunikasi efektif terhadap hasil belajar mahasiswa.

\section{Ucapan Terima Kasih}

Ucapan terima kasih diberikan kepada Fakultas Ilmu Komunikasi Universitas Tarumanagara, responden penelitian, keluarga, teman-teman, dan seluruh pihak yang membantuk peneliti dalam menyempurnakan penelitian ini.

\section{Daftar Pustaka}

Dimyati dan Mudjiono. (2006). Belajar dan Pembelajaran. Jakarta: PT. Rineke Cipta.

Karyadi, Bambang. (2017). Belajar Fotografi. Bogor: Nahlmedia.

Marcus, Sudjojo. (2010). Tak-Tik Fotografi. Jakarta: Bukune.

Murtiyasa, Budi. (2012). Pemanfaatan Teknologi Informasi dan Komunikasi Untuk Meningkatkan Kualitas Pembelajaran Matematika. Jurnal Teladan Vol.4 No. 1, 25-36.

Rakhmat, Jalaluddin. (2013). Psikologi Komunikasi. Bandung: PT. Remaja Rosda Karya.

Sudarma, I Komang. (2014). Fotografi. Yogyakarta: Graha Ilmu.

Sugiyono. (2017). Metode Penelitian Kuantitatif, Kualitatif, dan R\&D. Bandung: Alfabeta.

Sujarweni, Wiratna. (2019). Metodologi Penelitian. Yogyakarta: PT. Pustaka Baru. Winataputra, Udin S. (2007). Teori - Teori Belajar dan Pembelajaran. Jakarta: Universitas Terbuka. 